\title{
新規炭酸脱水酵素阻害剤ドルゾラミドの体内動態（II）：
}

ラットに打ける赤血球との結合および単回投与後の血中濃度

\author{
原 健一・長谷川拓郎・釰持とし江・畑 俊輔
}

\section{Metabolic Fate of Dorzolamide, a New Carbonic Anhydrase Inhibitor (II): Binding to Rat Erythrocytes, and Blood Concentration in Rats after Single Administration}

\author{
Ken'ichi Hara, Takuro Hasegawa, Toshie Kenmochi, Shunsuke Hata
}

Development Research Laboratories, Banyu Pharmaceutical Co.,Ltd., Saitama

\section{Summary}

Dorzolamide hydrochloride (MK-507), (-)-(4S,6S)-4-ethylamino-5,6-dihydro-6-methyl-4H-thieno-[2,3-b]-thiopyran-2-sulfonamide-7,7-dioxide monohydrochloride, is a new topical carbonic anhydrase inhibitor. The binding of dorzolamide and its $N$-deethylated metabolite (L-706,803) to rat erythrocytes was investigated, and the pharmacokinetics of dorzolamide in rats was studied after a single intravenous administration.

1. Dorzolamide was incorporated into rat erythrocytes rapidly, while the uptake of $\mathrm{L}-706,803$ was slower.

2. There were two types of binding site for dorzolamide and L-706,803 in rat erythrocytes. For both dorzolamide and L-706,803, the maximum binding capacity was about $60 \mu \mathrm{M}$ for the high affinity isozyme and $30 \mu \mathrm{M}$ for the low affinity isozyme.

3. The Kd values of dorzolamide and $\mathrm{L}-706,803$ for low affinity binding were 0.387 and $0.497 \mu \mathrm{M}$, respectively. The $\mathrm{Kd}$ values of dorzolamide and $\mathrm{L}-706,803$ for high affinity binding were about $1 / 100$ and $1 / 250$ of those for low affinity binding, respectively.

4. After administration of dorzolamide hydrochloride to rats at the dose of $0.5 \mathrm{mg} / \mathrm{kg}$, dorzolamide and L-706,803 were not detected in plasma. At the dose of $5 \mathrm{mg} / \mathrm{kg}$, the plasma half-lives of dorzolamide and L-706,803 were 1.0 and 2.6 $\mathrm{hr}$, respectively.

5. At the dose of $0.5 \mathrm{mg} / \mathrm{kg}$, the half-lives of dorzolamide and L-706,803 in blood were 157 and $116 \mathrm{hr}$, respectively, and decreased to respective values of 101 and $99 \mathrm{hr}$ after administration of $5 \mathrm{mg} / \mathrm{kg}$.

6. After administration of dorzolamide hydrochloride at the dose of $0.5 \mathrm{mg} /$ $\mathrm{kg}$, the blood AUC values of dorzolamide and L-706,803 were 1093 and $115 \mu \mathrm{g}$. $\mathrm{hr} / \mathrm{ml}$, respectively. The AUC value of dorzolamide at the dose of $5 \mathrm{mg} / \mathrm{kg}$ decreased by $50 \%$ and that of $\mathrm{L}-706,803$ increased about five-fold.

7. The $\mathrm{Vd}_{\mathrm{ss}}$ and $\mathrm{CL}_{\text {tot }}$ of dorzolamide were $99.9 \mathrm{ml} / \mathrm{kg}$ and $0.46 \mathrm{ml} / \mathrm{hr} / \mathrm{kg}$ after administration of $0.5 \mathrm{mg} / \mathrm{kg}$ and increased $15^{-}$and 25 -fold after $5 \mathrm{mg} / \mathrm{kg}$, respectively.

Key words : Dorzolamide, MK-507, Erythrocytes, Rats, Carbonic anhydrase, Binding, Pharmacokinetics 


\section{緒言}

緑内障の治療薬の一つとして炭酸脱水酵素 (CA) 阻害薬が用いられてきたが，いずれも経口 投与製剤であり，長期連用により種々の全身性の 副作用を引き起こすことが知られている1,2)。こ のため点眼で効果のある CA 阻害剤の開発が望ま れていた．塩酸ドルゾラミド $(\mathrm{MK}-507),(-)-$ (4S, 6S ) -4-ethylamino-5,6-dihydro-6-methyl$4 \mathrm{H}$-thieno-[2,3-b]-thiopyran-2-sulfonamide7,7-dioxide monohydrochloride は強力な CA 阻 害剂で点眼時の眼内移行性が良好なことから点眼 製剤として開発が進められており，臨床的にも優 れた効果が報告されている3-6)，前報でラットに ${ }^{14} \mathrm{C}$ 塩酸ドルゾラミドを静脈内あるいは経口投与 したのちの吸収，分布，代謝抢よび排泄に関する 検討を行ない，投与された放射能は赤血球と強く 結合すること，打よび血中放射能濃度推移に非線 形性が認められることを報告した ${ }^{7)}$.

今回, ドルゾラミド拈よびその N-脱エチル代 謝物のラット赤血球との結合, ならびに塩酸ドル ゾラミドをラットに静脈内投与した際の血中未変 化体抒よび $\mathrm{N}$-脱エチル体の濃度推移について検 討したのでその結果を報告する.

\section{実験材料および方法}

\section{1. 試験薬物および標品}

塩酸ドルゾラミドおよびその N-脱エチル代謝 物標品である L-706,803 ならびに HPLC 測定時 の内部標準物質である $\mathrm{MK}-417$ (S (+), [5,6-dihydro- $4 \mathrm{H}-4$-isobutylaminothieno $(2,3-\mathrm{b})$ thiopyran-2-sulfonamide-7,7-dioxide monohydrochloride]）は, Merck 社より提供を受けた．以上の 化合物の化学構造式を Fig. 1 に示した. 以下投 与量および濃度は全て遊離塩基換算值で示した。 その他の試薬はいずれも HPLC 規格品および市 販特級品を用いた。

\section{2. 試験動物}

雄性 Sprague-Dawley 系ラットを日本チャール スリバー株式会社より購入し，一週間以上予備飼 育したのち，7〜8 週龄で実験に供した．飼育は $22 \pm 2^{\circ} \mathrm{C}$, 湿度 $55 \pm 10 \%$ の条件下で行い，水は水 道水を，飼料はピュリナ5002を用いた。

\section{3. 赤血球の調製}

ラットをエーテル麻醉下腹部大動脈より採血 し, ヘパリン添加後へマトクリット值を測定した. $4^{\circ} \mathrm{C}$ で遠心分離し, 血漿を除去後 3 倍量のリンゲ 儿液で 3 回洗浄し,さらにトリス等張緩衝液 (10 mM Tris, $131 \mathrm{mM} \mathrm{NaCl}, 4 \mathrm{mM} \mathrm{KCl}, 3 \mathrm{mM}$

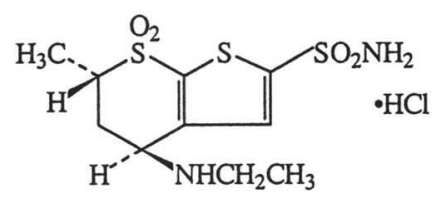

Dorzolamide hydrochloride
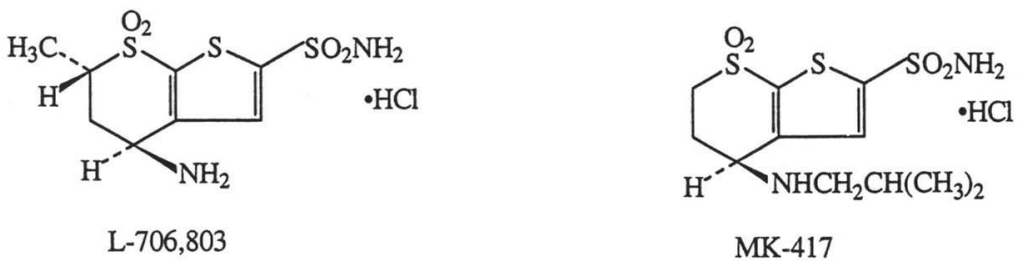

Fig. 1 Chemical structures of dorzolamide, L-706,803 and MK-417 
$\mathrm{CaCl}_{2}, \mathrm{pH} 7.4$, 以後 TBS と略す) で 2 回洗浄し た.

\section{4. 赤血球への経時的取り込み}

赤血球 $400 \mu l$ を $37^{\circ} \mathrm{C} て ゙ 2$ 分間プレインキュベ ーションしたのち, ドルゾラミドをたは L706,803 の 20 および $200 \mu \mathrm{M}$ の TBS 溶液 $600 \mu l$ を添加し， $37^{\circ} \mathrm{C}$ で経時的にインキュベートした. インキュベート終了後, 微量遠心機 (Kubota 1700）で遠心分離（12,000 rpm, $\left.2 \mathrm{~min}, 4^{\circ} \mathrm{C}\right)$ し, 上清中の薬物濃度を HPLCにより測定した.

\section{5. 赤血球との結合}

ラット赤血球 $400 \mu l$ を $37^{\circ} \mathrm{C}$ で 2 分間プレイン キュベーションしたのち，ドルゾラミドの 25〜 $200 \mu \mathrm{M}$ TBS 溶液 $600 \mu l$ を添加し, $37^{\circ} \mathrm{C}$ で15分 間インキュベートした. L-706,803 は，20２00 $\mu \mathrm{M}$ の TBS 溶液 $600 \mu l$ を添加し, $37^{\circ} \mathrm{C}$ で 60 分 間インキュベートした. インキュベート終了後微 量遠心機で遠心分離 $\left(12,000 \mathrm{rpm}, 2 \mathrm{~min}, 4^{\circ} \mathrm{C}\right)$ し, 上清を限外濾過（ウルトラフリーC3LGC， ミリポア）後得られた濾液中の薬物濃度を HPLCにより測定した.

\section{6. 投与液の調製および投与方法}

投与液は，塩酸ドルゾラミドに生理食塩水を加 えて $0.5 \mathrm{mg} / \mathrm{ml}, 5 \mathrm{mg} / \mathrm{ml}$ 溶液を調製した. 投与 は尾静脈より行い, 一群 3 匹とした。投与量は $0.5 \mathrm{mg} / \mathrm{ml} / \mathrm{kg}$ および $5 \mathrm{mg} / \mathrm{ml} / \mathrm{kg}$ とした.

7. 血液中および血漿中ドルゾラミドおよび $\mathrm{L}^{-}$ 706,803 の測定

投与後 $0.5,1,2,4,8,24,72,120,168$ 時間に工 一テル麻酔下腹部大動脈よりへパリン処理したシ リンジを用いて採血した，血液はその一部を用い てへマトクリット值を測定後 $1 \mathrm{~m} l$ を採取し，イ オン交換水 $1 \mathrm{~m} l$ を加えて混合し，血液濃度測定 用サンプルとした．残りの血液は遠心分離し血漿 サンプルを得た。血漿は, 内部標準物質として $\mathrm{MK}-417$ を添加後, $0.2 \mathrm{M}$ リン酸緩衝液（pH
8.0）を加え，酢酸エチルで抽出した. 分取した 有機層に $25 \mathrm{mM}$ リン酸を加え逆抽出後, リン酸 層をHPLCに注入した．血液は10\%トリクロロ 酢酸で溶血後, 血漿と同様に処理した.

\section{HPLC 測定}

ポンプは $880 \mathrm{PU}$ (日本分光), UV 検出器は 875UV（日本分光）または 116 (Gilson) を用い た. カラムは Bondesil C-18 $4.6 \times 50 \mathrm{~mm}, 3 \mu \mathrm{m}$ (Analytichem) および Ultrasphere C-8 $4.6 \times$ $150 \mathrm{~mm}, 5 \mu \mathrm{m}$ （Beckman）を直列に連結して使 用した。

〈血漿および血液中濃度測定〉

移動相 : $0.085 \% \mathrm{H}_{3} \mathrm{PO}_{4}-1.6 \mathrm{~g} / l$ Sodium octanesulfonate $/ \mathrm{CH}_{3} \mathrm{CN}(75: 25)$

流速 : $1 \mathrm{ml} / \mathrm{min}$ カラム温度 : $20^{\circ} \mathrm{C} \mathrm{UV}$ 検出波 長 : $252 \mathrm{~nm}$

本測定法の定量限界はドルゾラミド，L706,803 ともに血漿で $10 \mathrm{ng} / \mathrm{ml}$ ，血液で $50 \mathrm{ng} /$ $\mathrm{m} l$ であった.

〈赤血球との結合実験〉

移動相 :

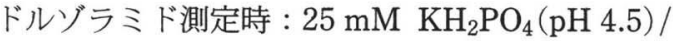
$\mathrm{CH}_{3} \mathrm{CN}(88: 12)$

L-706,803 測定時 : $25 \mathrm{mM} \quad \mathrm{Na}_{2} \mathrm{HPO}_{4}-10 \mathrm{mM}$ Citric acid (pH 5.1) $/ \mathrm{CH}_{3} \mathrm{CN}(88: 12)$

流速 : $1 \mathrm{ml} / \mathrm{min}$ カラム温度 : $40^{\circ} \mathrm{C} \mathrm{UV}$ 検出波 長 : $252 \mathrm{~nm}$

本測定法の定量限界はドルゾラミド， $\mathrm{L}-$ 706,803 ともに $10 \mathrm{ng} / \mathrm{ml}$ であった.

\section{9. 結合定数の算出}

結合パラメーターは 5-parameter model（式 1）を用いた非線形最小二乗法プログラム (Grafit $^{R}$, Erithacus Software) により算出した.

$$
\begin{aligned}
\mathrm{Cb}= & \mathrm{B}_{\max } 1 \times \mathrm{Cf} /(\mathrm{Kd} 1+\mathrm{Cf})+\mathrm{B}_{\max } 2 \\
& \times \mathrm{Cf} /(\mathrm{Kd} 2+\mathrm{Cf})+\mathrm{C} \times \mathrm{Cf}
\end{aligned}
$$

$\mathrm{Cb}$ : 結合薬物濃度 $\mathrm{Cf}$ : 非結合薬物濃度 $\mathrm{B}_{\max }$ : 最大薬物結合濃度 $\mathrm{Kd}$ : 解離定数 $\mathrm{C}:$ 非特異的結合定数 
10. ファーマコキネティックパラメーターの算出 血液（血漿）中のドルゾラミドおよびL706,803 濃度よりファーマコキネティックパラメ ーターを算出した。消失半減期（ $\mathrm{t}_{1 / 2}$ ) は濃度の 対数一時間プロットの消失相の直線部分の傾き ( $\mathrm{Ke})$ を最小二乗法により求め $\mathrm{t}_{1 / 2}=0.693 / \mathrm{Ke}$ よ り算出した。血液 (血漿) 中濃度時間曲線下面積 $\left(\mathrm{AUC}_{0-\infty}\right)$ は台形法により求め, 最終測定時点 以降は消失相の直線部分を無限大時間まで外挿し て求めた. 全身クリアランス $\left(\mathrm{CL}_{\mathrm{tot}}\right)$ は投与量 を $\mathrm{AUC}_{0-\infty}$ で除して求めた. 定常状態分布容積
$\left(\mathrm{Vd}_{\mathrm{ss}}\right)$ は式 2 により求めた.

$$
\mathrm{Vd}_{\mathrm{ss}}=\mathrm{CL}_{\mathrm{tot}} \times \int_{0}^{\infty} \mathrm{tCp} \mathrm{dt} / \int_{0}^{\infty} \mathrm{Cpdt} \quad \text { (式 2) }
$$

ここで $\mathrm{t}$ は投与後時間, $\mathrm{Cp}$ は時間 $\mathrm{t}$ における血 漿中または血液中濃度

結果

1. ラット赤血球中へのドルゾラミドおよび $\mathbf{L}-$ 706,803 の取り込み

ドルゾラミドおよびL-706,803 のラット赤血 球への取り込みをFig. 2 に示した. ドルゾラミ

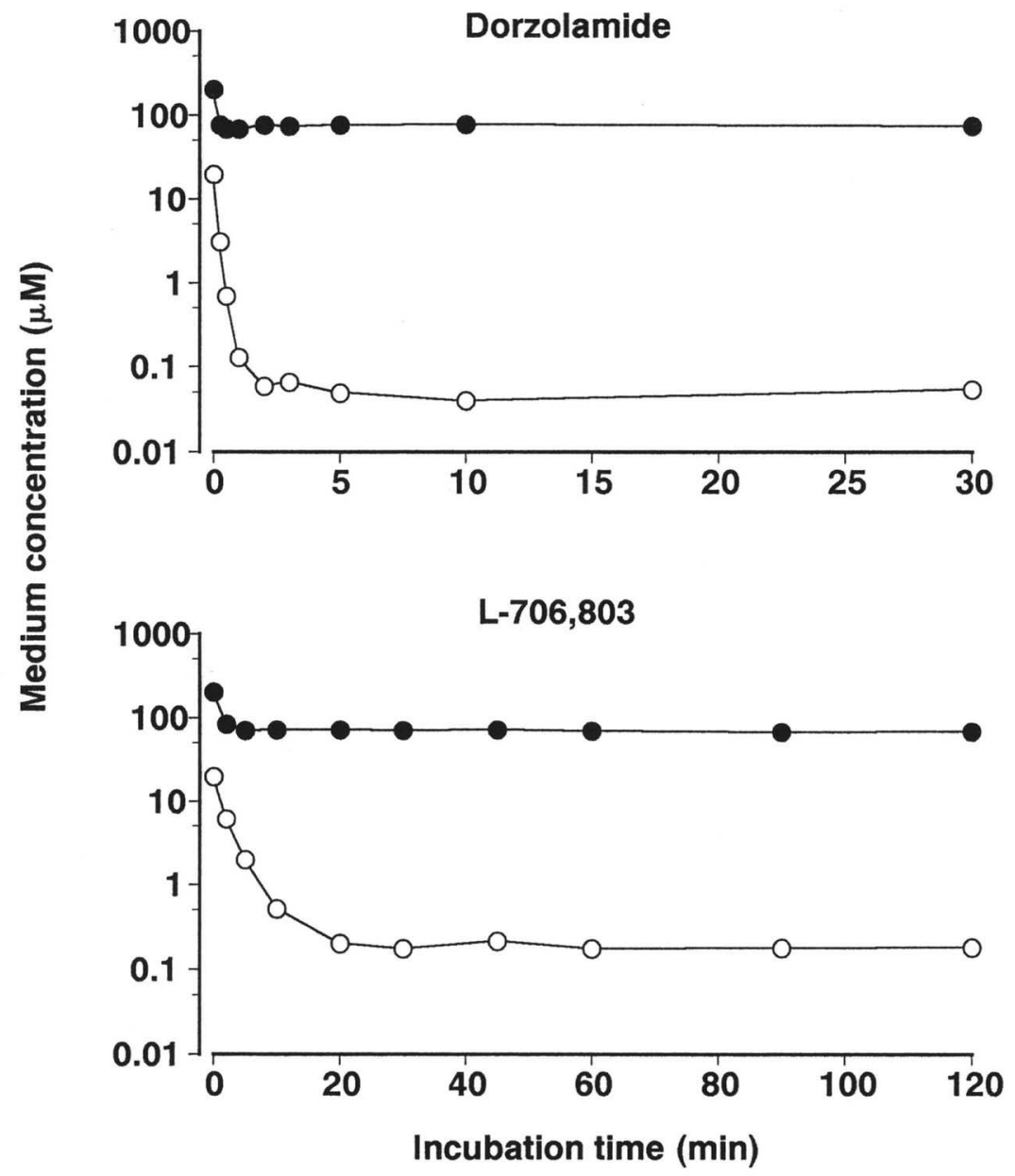

Fig. 2 Decrease of dorzolamide and L-706,803 in the incubation medium by the uptake into rat erythrocytes

Each point represents the mean of three (dorzolamide) or two ( $\mathrm{L}-706,803) \mathrm{de}$ terminations. $\bigcirc$, addition of $20 \mu \mathrm{M}$; , addition of $200 \mu \mathrm{M}$ 
ドのラット赤血球中への取り込みは速く, 20 $\mu \mathrm{M}$ 添加時には約 2 分で, $200 \mu \mathrm{M}$ 添加時には約 30秒でメディウム中濃度は平衡に達した。これ に比べ L-706,803の取り込みは遅く $20 \mu \mathrm{M}, 200$ $\mu \mathrm{M}$ 添加時それぞれ 20 および 5 分で平衡に達し た. $20 \mu \mathrm{M}$ 添加時のドルゾラミドおよび $\mathrm{L}-$ 706,803 のメディウム中からの消失速度定数は, それぞれ 4.9 および $0.35 \mathrm{~min}^{-1}$ であった。

2. ラット赤血球とドルゾラミドおよび $\mathrm{L}-$ 706,803 の結合

ドルゾラミドおよび L-706,803 のラット赤血 球との結合を Scatchard plot で Fig. 3 に示した. 両薬剤とも Scatchard plotは, 非線形を示した ことから，2 種類以上の結合部位があることが示 唆された。そこで 2 種類の特異的結合と非特異 的結合を想定した 5-parameter model にて解析 した結果，実測値は理論式と良く合致した。これ らの解離定数 $(\mathrm{Kd})$ および最大薬物結合濃度 $\left(\mathrm{B}_{\max }\right)$ を Table I に示した。ドルゾラミドの $\mathrm{Kd} 1$ および $\mathrm{Kd} 2$ は，それぞれ $0.004 \mu \mathrm{M}$ 抢よび
Table I Binding parameters of dorzolamide and $\mathrm{L}-706,803$ in rat erythrocytes

\begin{tabular}{lccccc}
\hline \multicolumn{1}{c}{ Compound } & $\begin{array}{c}\mathrm{Kd} 1 \\
(\mu \mathrm{M})\end{array}$ & $\begin{array}{c}\mathrm{B}_{\max } 1 \\
(\mu \mathrm{M})\end{array}$ & $\begin{array}{c}\mathrm{Kd} 2 \\
(\mu \mathrm{M})\end{array}$ & $\begin{array}{c}\mathrm{B}_{\max } 2 \\
(\mu \mathrm{M})\end{array}$ & $\mathrm{C}$ \\
\hline Dorzolamide & 0.004 & 56.5 & 0.387 & 25.5 & 0.580 \\
L-706,803 & 0.002 & 56.7 & 0.497 & 31.4 & 0.272
\end{tabular}

Parameters were determined from the mean values by nonlinear regression analysis of the equation shown in Materials and Methods using the mean of duplicate incubations.

$0.387 \mu \mathrm{M}$ と高親和性部位との結合は，低親和性 部位との結合に比べ約100倍強かった。ドルゾラ ミドの $\mathrm{B}_{\max } 1$ および $\mathrm{B}_{\max } 2$ は，それぞれ 56.5 およ び $25.5 \mu \mathrm{M}$ と高親和性部位の $\mathrm{B}_{\max }$ は，低親和性 部位のそれよりも約 2 倍大きい値を示した。 L706,803 の $\mathrm{Kd} 1$ は $0.002 \mu \mathrm{M}, \mathrm{Kd} 2$ は $0.497 \mu \mathrm{M}$ であり, Kd2/Kd1 の比は約 250 とドルゾラミド 同様, 高親和性部位への選択的な結合が認められ た. $\mathrm{L}-706,803$ の $\mathrm{B}_{\max } 1$ 打よび $\mathrm{B}_{\max } 2$ は，ドル ゾラミドとほぼ同じ值を示した.
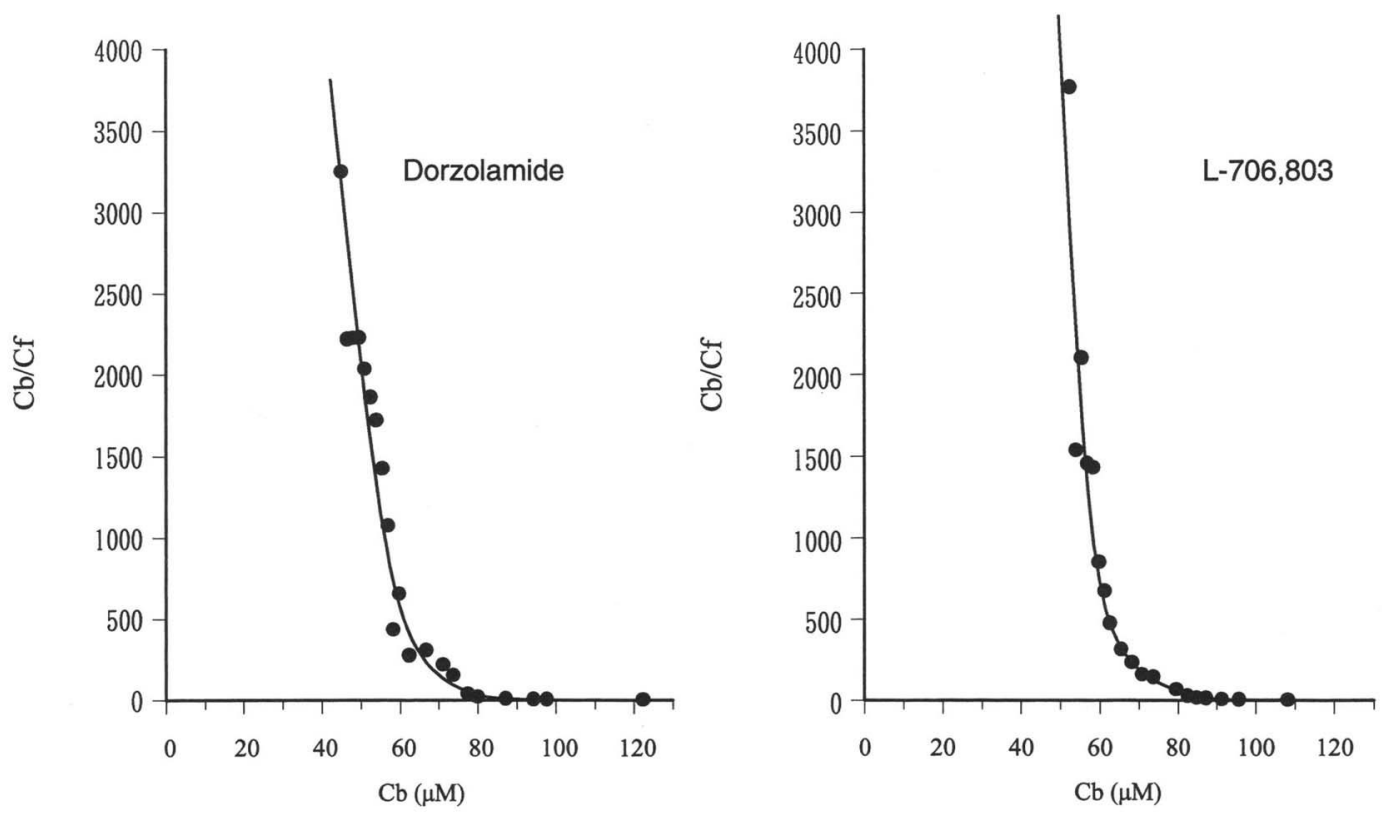

Fig. 3 Scatchard plots of the binding of dorzolamide and L-706,803 to rat erythrocytes Each point represents the mean of two determinations. 
3. 血液および血漿中ドルゾラミドおよび L706,803 濃度推移

塩酸ドルゾラミド $0.5 \mathrm{mg} / \mathrm{kg}$ および $5 \mathrm{mg} / \mathrm{kg}$ を静脈内投与したのちの血漿中および血液中ドル ゾラミドおよび $\mathrm{N}-$ 脱エチル代謝物（L-706,803） の経時的濃度推移を Fig. 4 に，投与後24時間ま での赤血球中のドルゾラミドおよび L-706,803 濃度推移をモル濃度に換算して Fig. 5 に示した. また, 血液および血墏中濃度から求めたファーマ コキネティックパラメーターを Table II に示し た.

$0.5 \mathrm{mg} / \mathrm{kg}$ 投与時, 血漿中ドルゾラミド, L-
706,803 濃度はともに定量限界以下であった．投 与後30分から 8 時間までの血液中ドルゾラミド 濃度は5.8〜 $6.3 \mu \mathrm{g} / \mathrm{m} l$ とほぼ一定濃度を維持し， この時点の赤血球中濃度は約 $50 \mu \mathrm{M}$ であった. 血液中ドルゾラミドの消失半減期（ $\mathrm{t}_{1 / 2}$ ) は 157 時間で, 投与後168時間では投与後 8 時間の $35 \%$ まで減少した．血液中 L-706,803 濃度は投与後 徐々に増加し，投与後72時間から120時間で約 $0.4 \mu \mathrm{g} / \mathrm{ml}$ の最高値に達した. 血液中のドルゾラ ミドおよびL-706,803の $\mathrm{AUC}_{0-\infty}$ はそれぞれ $1093 \mu \mathrm{g} \cdot \mathrm{hr} / \mathrm{ml}$ および $115 \mu \mathrm{g} \cdot \mathrm{hr} / \mathrm{m} l$ であった.

$5 \mathrm{mg} / \mathrm{kg}$ 投与後 30 分の血漿中ドルゾラミドお

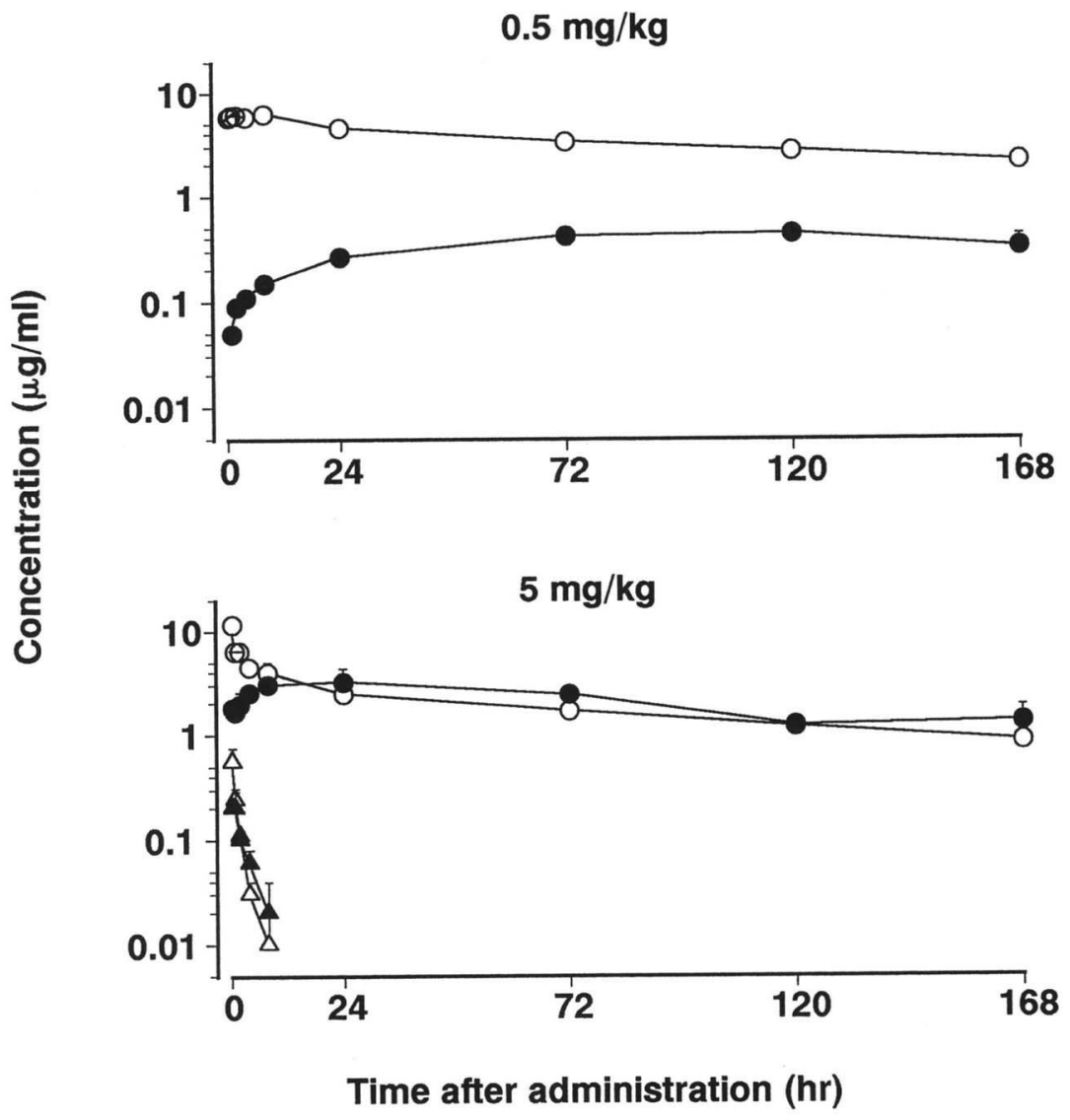

Fig. 4 Blood and plasma concentrations of dorzolamide and L-706,803 after single intravenous administration of dorzolamide hydrochloride to male rats at doses of 0.5 and $5 \mathrm{mg} / \mathrm{kg}$

Each point represents the mean \pm S.D. of three rats.

$\bigcirc$, blood concentration of dorzolamide; $\mathbf{O}$, blood concentration of $\mathrm{L}-706,803$

$\triangle$, plasma concentration of dorzolamide; $\boldsymbol{\Delta}$, plasma concentration of $\mathrm{L}-706,803$ 
Table II Pharmacokinetic parameters of dorzolamide and L-706,803 in plasma and blood after intravenous administration of dorzolamide hydrochloride to rats at doses of 0.5 and 5 $\mathrm{mg} / \mathrm{kg}$

$0.5 \mathrm{mg} / \mathrm{kg}$

\begin{tabular}{|c|c|c|c|c|}
\hline & $\underset{(\mu \mathrm{g} \cdot \mathrm{hr} / \mathrm{m} l)}{\mathrm{AUC}_{0-\infty}}$ & 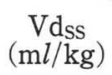 & $\begin{array}{c}\mathrm{CL}_{\text {tot }} \\
(\mathrm{m} l / \mathrm{hr} / \mathrm{kg})\end{array}$ & $\begin{array}{l}\mathrm{t}_{1 / 2} \\
(\mathrm{hr})\end{array}$ \\
\hline \multicolumn{5}{|l|}{$\langle$ Plasma $\rangle$} \\
\hline Dorzolamide & - & - & - & - \\
\hline $\mathrm{L}-706,803$ & - & - & - & - \\
\hline \multicolumn{5}{|l|}{$\langle$ Blood $\rangle$} \\
\hline Dorzolamide & 1093 & 99.9 & 0.46 & 157 \\
\hline L-706, 803 & 115 & - & - & 116 \\
\hline
\end{tabular}

$5 \mathrm{mg} / \mathrm{kg}$

\begin{tabular}{lcccc}
\hline & $\begin{array}{c}\mathrm{AUC}_{(0-\infty)} \\
(\mu \mathrm{g} \cdot \mathrm{hr} / \mathrm{m} l)\end{array}$ & $\begin{array}{c}\mathrm{Vd} \mathrm{ms} \\
\mathrm{m} l / \mathrm{kg})\end{array}$ & $\begin{array}{c}\mathrm{CL}_{\text {tot }} \\
(\mathrm{m} l / \mathrm{hr} / \mathrm{kg})\end{array}$ & $\begin{array}{c}\mathrm{t}_{1 / 2} \\
(\mathrm{hr})\end{array}$ \\
\hline$\langle$ Plasma & & & & \\
Dorzolamide & 0.81 & 13775 & 6173 & 1.0 \\
$\begin{array}{l}\text { L-706, 803 } \\
\langle\text { Blood〉 }\end{array}$ & 0.78 & - & - & 2.6 \\
$\begin{array}{l}\text { Dorzolamide } \\
\text { L-706, 803 }\end{array}$ & 442 & 1503 & 11.3 & 101 \\
\hline
\end{tabular}

Parameters were calculated from mean plasma concentrations $(n=3)$.

よびL-706,803 濃度は，それぞれ0.55および $0.20 \mu \mathrm{g} / \mathrm{m} l$ であった．以後ドルゾラミドは $\mathrm{t}_{1 / 2}$ $1.0 \mathrm{hr}, \mathrm{L}-706,803$ は $2.6 \mathrm{hr}$ で消失し, 投与後 24 時間ではいずれも検出限界以下となった．血液中 ドルゾラミド濃度は投与後 30 分で $11.7 \mu \mathrm{g} / \mathrm{m} l$ を 示したのち二相性で消失し, 投与後 24 時間以降 の $t_{1 / 2}$ は $101 \mathrm{hr}$ であった. 赤血球中ドルゾラミ ド濃度は投与後30分， 1 および168時間でそれぞ れ95.9, 55.2 および $7.4 \mu \mathrm{M}$ であった。血液中 $\mathrm{L}-$ 706,803 濃度は投与後徐々に上昇し投与後 24 時間 で $3.25 \mu \mathrm{g} / \mathrm{ml}$ の最高值に達したのち $\mathrm{t}_{1 / 2} 99 \mathrm{hr}$ で減少し, 投与後 168 時間では $1.33 \mu \mathrm{g} / \mathrm{ml}$ とな った．投与後30分， 1 拈よび168時間の赤血球中

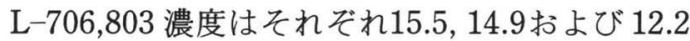
$\mu \mathrm{M}$ であった。血液中濃度のドルゾラミドおよ びL-706,803の $\mathrm{AUC}_{0-\infty}$ はそれぞれ $442 \mu \mathrm{g} \cdot \mathrm{hr} /$ $\mathrm{m} l$ および $521 \mu \mathrm{g} \cdot \mathrm{hr} / \mathrm{m} l$ であり, ドルゾラミド
は $0.5 \mathrm{mg} / \mathrm{kg}$ 投与時の約 $1 / 2, \mathrm{~L}-706,803$ は 0.5 $\mathrm{mg} / \mathrm{kg}$ 投与時の約 5 倍高い值を示した. $5 \mathrm{mg} /$ $\mathrm{kg}$ 投与時の血漿中濃度の $\mathrm{AUC}_{0-\infty}$ は, ドルゾラ ミド抢よび $\mathrm{L}-706,803$ ともに約 $0.8 \mu \mathrm{g} \cdot \mathrm{hr} / \mathrm{m} l$ で あり，それぞれ血液中濃度の AUC の約 $1 / 550$ お

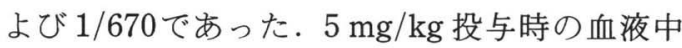
ドルゾラミドの $\mathrm{Vd}_{\mathrm{ss}}$ および $\mathrm{CL}_{\text {tot }}$ は $0.5 \mathrm{mg} / \mathrm{kg}$

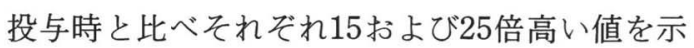
した.

\section{考察}

ラットに ${ }^{14} \mathrm{C}$ 塩酸ドルゾラミドを静脈内あるい は経口投与した際, 血液中放射能のほとんどは赤 血球中に存在し, 赤血球との強い結合が示唆され た7）。なた，主代謝物である N-脱エチル体（L$706,803)$ はドルゾラミド同様 CA 阻害活性を有 するが，阻害活性は CA-II に対してはドルゾラ ミドよりも弱く CA-I に対しては強いことが確認 されている (米国メルク社, 社内資料). そこで, in vitroにおいて本薬剤および L-706,803 とラッ 卜赤血球との結合性について検討した.

ラット赤血球中への L-706,803の取り込み速 度は，ドルゾラミドに比べ約14倍遅かった。こ の取り达み速度の差異はヒト赤血球においても認 められており8)，L-706,803 の脂溶性がドルゾラ ミドよりも低いためと考えられる.しかしながら 両化合物ともラット赤血球内への取り込み速度は ヒト赤血球内への取り込みと比べると, 約 $2 \sim 3$ 倍速く種差が認められた. この様な赤血球内への 取り込み速度に種差があることはドルゾラミドと 同様, thienothiopyran-2-sulfonamide の構造を 有する MK-927においても認められている9). ラット赤血球内にはドルゾラミド， L-706,803 と もに 2 種類の結合部位が認められ，高親和性， 低親和性のいずれの結合部位においても両化合物 の $\mathrm{Kd}$ および $\mathrm{B}_{\max }$ に大きな差は認められなかっ た。一般にスルフォンアミド系のCA 阻害剤は $\mathrm{CA}$ と強く結合し，CA-I よりも CA-II を強く阻 害することが知られている10-12)。 また，ヒト赤 血球中でもドルゾラミドの特異的結合部位は 2 


\section{$0.5 \mathrm{mg} / \mathrm{kg}$}

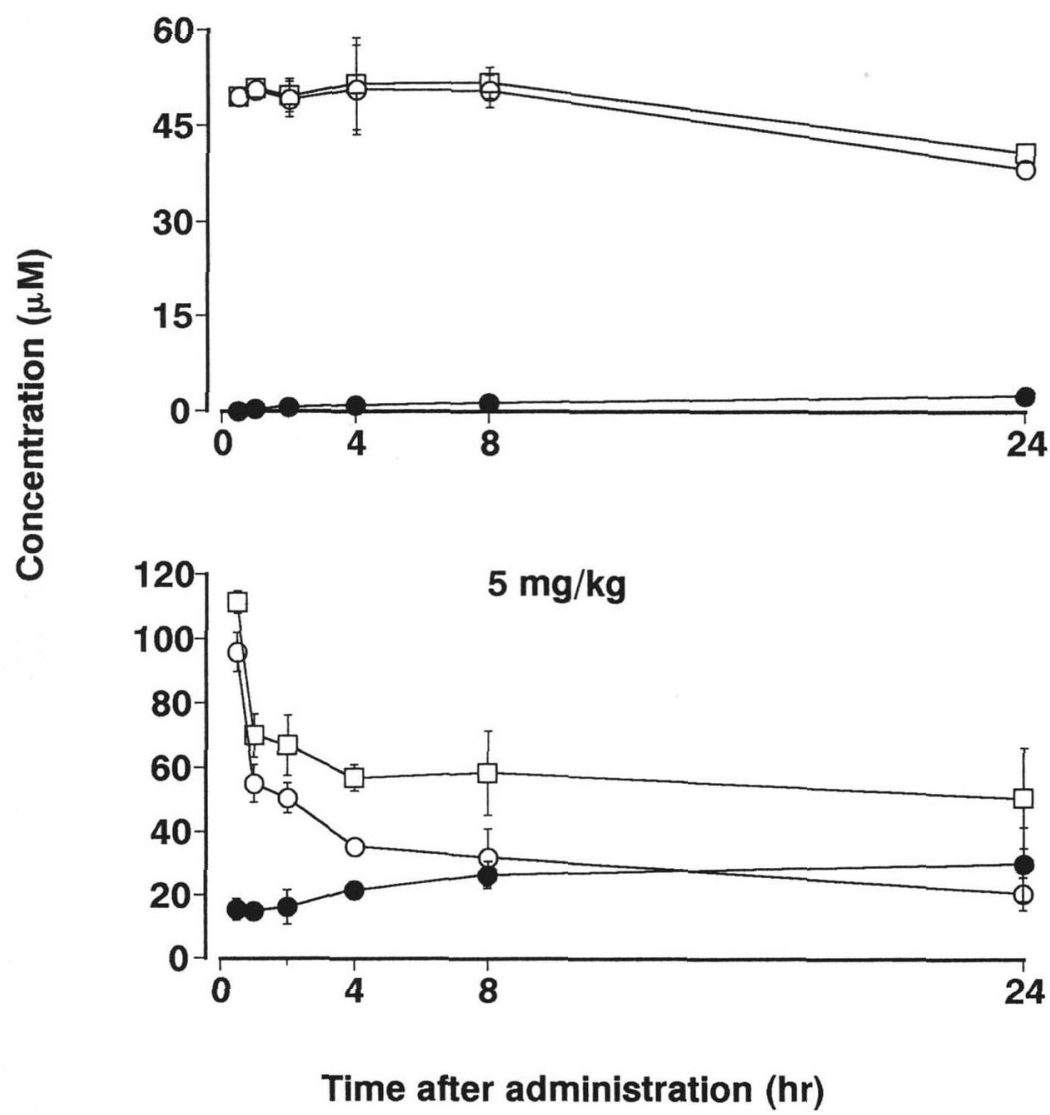

Fig. 5 Concentrations of dorzolamide and L-706,803 in rat erythrocytes after single intravenous administration of dorzolamide hydrochloride at doses of 0.5 and 5 $\mathrm{mg} / \mathrm{kg}$

Each point represents the mean \pm S.D. of three rats.

$\bigcirc$, dorzolamide; $, \mathrm{L}-706,803 ; \square$, total concentration

種類存在し, 高親和性部位は CA-II との, 低親 和性部位は CA-I との結合であること，さらに L-706,803 もヒト CA と結合し，結合部位はドル ゾラミドと競合することが明らかとなっている8). ラット赤血球内に㧍けるドルゾラミドおよび L706,803 の低親和性部位と高親和性部位の $\mathrm{B}_{\text {max }}$ の合計は80 90 $\mu \mathrm{M}$ でありラット赤血球中の総 $\mathrm{CA}$ 濃度の約90 $100 \mu \mathrm{M}^{13,14)}$ と一致しているこ とからラット赤血球内に扔いてもドルゾラミド拈 よび L-706,803 は CA と結合しているものと思 われる，ドルゾラミドは CA-II の強力な阻害剤(4)
でヒト CA-II に対する親和性は CA-I に比べ約 4000 倍強く, 既存の CA 阻害剂よりはるかに強 い選択性を示す8)。 ラット赤血球内には CA-I, CA-II, CA-III が存在し，この内 CA-I 打よび CA-II が主であることが報告されている15-17). Lönnerholm ら ${ }^{18)}$ はラット血液中 CA-II 濃度は 約 $29 \mu \mathrm{M}$ と報告している. ラット血液のへマト クリット值を $45 \%$ とすると赤血球中 CA-II 濃度 は約 $70 \mu \mathrm{M}$ と算出され, 高親和性部位の $\mathrm{B}_{\max }$ 約 $60 \mu \mathrm{M}$ とほほ一致することからラット赤血球内 の高親和性部位は CA-II, 低親和性部位は CA-I 
と推定される．高親和性，低親和性部位に対する ドルゾラミドの $\mathrm{Kd}$ 值の差は約 100 倍であり， CA-II に選択的であったが，ヒトの4000倍8) と比 べると選択性が低かった。・これは低親和性部位に 対する結合がヒトよりも強いためである。 また， ヒトでは L-706,803 の CA-II に対する選択性は ドルゾラミドに比べ低かったが，ラットではドル ゾラミドとほぼ同様であった．この様な同種の CA でも親和性に種差があることについては， MK-927 においても報告9)されている.

${ }^{14} \mathrm{C}$ 塩酸ドルゾラミド静脈内投与時の血液中放 射能濃度推移は $1 \mathrm{mg} / \mathrm{kg}$ まではほぼ線形性を保 つがそれ以上の投与量では非線形性を示すことが 明らかとなっている7). 今回, 血中放射能濃度が 飽和レベルに達しない低投与量群として $0.5 \mathrm{mg} /$ $\mathrm{kg}$ を，飽和レベルを越える高投与量群として 5 $\mathrm{mg} / \mathrm{kg}$ を設定し，ラットに塩酸ドルゾラミドを 静脈内投与したのちのドルゾラミドおよびその $\mathrm{N}$-脱エチル代謝物（L-706,803）の血液中，血 漿中濃度推移について検討した. $0.5 \mathrm{mg} / \mathrm{kg}$ 投与 時では血墏中ドルゾラミド, L-706,803 濃度は定 量限界以下であり, 血液中からのドルゾラミドの 消失は緩慢であった。 また，赤血球中 $\mathrm{L}-$ 706,803 濃度はドルゾラミドに比べて低いものの 投与後 72 から 120 時間まで僅かずつ上昇した. 5 $\mathrm{mg} / \mathrm{kg}$ 投与時では $0.5 \mathrm{mg} / \mathrm{kg}$ 投与時に比べ投与 後 8 時間までの血液中ドラゾラミドの消失は速 く投与後 4 時間以降のドルゾラミド濃度は 0.5 $\mathrm{mg} / \mathrm{kg}$ 投与時よりも低值を示した. $5 \mathrm{mg} / \mathrm{kg}$ 投 与時の血液中 $\mathrm{L}-706,803$ 濃度は $0.5 \mathrm{mg} / \mathrm{kg}$ 投与 時に比べ著しく上昇し, $\mathrm{AUC}_{0-\infty}$ は $0.5 \mathrm{mg} / \mathrm{kg}$ 投与時の約 5 倍高い值を示した.

以上の低投与量群 $(0.5 \mathrm{mg} / \mathrm{kg})$ と高投与量群 $(5 \mathrm{mg} / \mathrm{kg})$ で見られた血中動態の差は赤血球中 CA との飽和のある結合によるものと考えられる.

$0.5 \mathrm{mg} / \mathrm{kg}$ 投与時の血液中ドルゾラミドの $\mathrm{Vd}_{\mathrm{ss}}$ はほぼ血液量に相当したが，これは赤血球中 CA とドルゾラミドとの結合が飽和に達しないため投 与したドルゾラミドは, ほとんどが赤血球中に取 り込まれるためと考えられる。したがって肝蔵に
移行するドルゾラミドは少なく L-706,803への 代謝も低いと考えられる. $0.5 \mathrm{mg} / \mathrm{kg}$ 投与時の血 液中 $\mathrm{L}-706,803$ 濃度が投与後72時間以降の遅い 時点で最高値に達するのは, 赤血球からのドルゾ ラミドの緩慢な消失に伴い僅かずつ生成する L706,803 が徐々に赤血球内の CA と結合するため と考えられる. $5 \mathrm{mg} / \mathrm{kg}$ 投与群では，血液中ド ルゾラミドの $\mathrm{Vd}_{\mathrm{ss}}$ が $0.5 \mathrm{mg} / \mathrm{kg}$ 投与時の約 15 倍 に増加したが，これは投与後早い時点において赤 血球中 CA は完全に飽和され, 非結合型の割合が 増加することにより肝臓への移行が増加するため と考えられる. $0.5 \mathrm{mg} / \mathrm{kg}$ 投与時に比べ $5 \mathrm{mg} /$ $\mathrm{kg}$ 投与時の血液中 AUC がドルゾラミドでは減 少，L-706,803 では増加したのは L-706,803の CA-I および CA-II に対する親和性がドルゾラミ ドとほほ等しいため, 肝臓で生成した L706,803 が赤血球中の CA と結合しているドルゾ ラミドと競合的に置換するためと考えられる。ま た，赤血球中のドルゾラミドおよび $\mathrm{L}-706,803$ の合計濃度推移は約 $60 \mu \mathrm{M}$ を境にして二相性を 示した $($ Fig. 5) . 赤血球中高親和性部位 $(\mathrm{CA}-$ II) の $\mathrm{B}_{\max }$ が約 $60 \mu \mathrm{M}$ であることから速い消失 相は CA-I との結合, 遅い消失相部分は CA-II との結合が関与するものと考えられる，以上，低 投与量群と高投与量群の血中動態に見られた差異 はドルゾラミド，L-706,803 がともに赤血球中 CA-II と強く結合し，その結合には飽和がある ことに起因するものと考えられる.

\section{要 約}

ラットに抢けるドルゾラミドおよびその N-脱 エチル代謝物とラット赤血球との結合性について 検討した. さらに，ラットに塩酸ドルゾラミドを 静脈内投与した際のドルゾラミドおよび $\mathrm{L}-$ 706,803 の血中濃度推移について検討した.

1. ドルゾラミドのラット赤血球中への取り达 みは L-706,803 よりも速かった.

2. ドルゾラミド, $\mathrm{L}-706,803$ ともにラット赤 血球内では 2 種類の結合部位が認められ, 高親 和性部位および低親和性部位の最大薬物結合濃度 
はそれぞれ約 60 および $30 \mu \mathrm{M}$ であった

3. ドルゾラミドおよび L-706,803 の低親和 性部位の Kd 値は，それぞれ0.387および 0.497 $\mu \mathrm{M}$ であった。ドルゾラミドおよび $\mathrm{L}-706,803$ の高親和性部位の $\mathrm{Kd}$ 值はそれぞれ低親和性部位 の約 $1 / 100$ および $1 / 250$ であった。

4. 塩酸ドルゾラミドをラットに静脈内投与し た際， $0.5 \mathrm{mg} / \mathrm{kg}$ では血漿中にドルゾラミドおよ び L-706,803 は認められなかった. $5 \mathrm{mg} / \mathrm{kg}$ 投 与時では僅かに認められ，消失半減期はドルゾラ ミドが1.0時間, L-706,803 が2.6時間であった.

5. 塩酸ドルゾラミド $0.5 \mathrm{mg} / \mathrm{kg}$ を静脈内投 与した際, 血液中ドルゾラミドおよびL706,803 の消失半減期はそれぞれ 157 および 116 時間であった. $5 \mathrm{mg} / \mathrm{kg}$ 投与時の消失半減期は それぞれ101および99時間であった。

6. $0.5 \mathrm{mg} / \mathrm{kg}$ 投与時の血液中ドルゾラミドお よびL-706,803の AUCは，それぞれ1093およ び $115 \mu \mathrm{g} \cdot \mathrm{hr} / \mathrm{ml}$ であったが， $5 \mathrm{mg} / \mathrm{kg}$ 投与時で はドルゾラミドの AUC は $0.5 \mathrm{mg}$ 投与時の約 $1 /$ 2 に減少した。 L-706,803のAUC は逆に約 5 倍 上昇した.

7. $0.5 \mathrm{mg} / \mathrm{kg}$ 投与時の血液中ドルゾラミドの $\mathrm{Vd}_{\mathrm{ss}}$ 打よび $\mathrm{CL}_{\text {tot }}$ はそれぞれ $99.9 \mathrm{~m} l / \mathrm{kg}$ および $0.46 \mathrm{ml} / \mathrm{hr} / \mathrm{kg}$ であった. $5 \mathrm{mg} / \mathrm{kg}$ 投与時の $\mathrm{Vd}_{\mathrm{ss}}$ 打よび $\mathrm{CL}_{\text {tot }}$ はそれぞれ $0.5 \mathrm{mg} / \mathrm{kg}$ 投与時 の15および25倍であった。

\section{文献}

1) Epstein, D. L. and Grant, W. M.: Carbonic anhydrase inhibitor side effects; serum chemical analysis. Arch. Ophthalmol., 95: 1378-1382 (1977).

2) Lichter, P. R., Newman, L. P., Wheeler, N. C. and Beall, O. V.: Patient tolerance to carbonic anhydrase inhibitors. Am. J. Ophthalmol., 85: 495-502 (1978).

3) Sugrue, M. F., Mallorga, P., Schwam, H., Baldwin, J. J. and Ponticello, G. S.: A comparison of L-671, 152 and MK-927, two topically effective ocular hypotensive carbonic anhydrase inhibitors, in experimental animals. Curr. Eye Res., 9: 607615 (1990).

4) Wang, R. F., Serle, J. B., Podos, S. M. and Sugrue, M. F.: The ocular hypotensive effect of the topical carbonic anhydrase inhibitor L-671, 152 in glaucomatous monkeys. Arch. Ophthalmol., 108: 511513 (1990).

5) Wang, R. F., Serle, J. B., Podos, S. M. and Sugrue, M. F.: MK-507 (L-671, 152), a topically active carbonic anhydrase inhibitor, reduces aqueous humor production in monkeys. Arch. Ophthalmol., 109: 1297-1299 (1991).

6) Hiett, J. A. and Dockter, C. A.: Topical carbonic anhydrase inhibitors: a new perspective in glaucoma therapy. Optom. Clin., 2: 97-112 (1992).

7）原 健一, 長谷川拓郎, 鈒持とし江, 江角凱夫, 神 義容, 根本裕之: 新規炭酸脱水酵素阻害剤 Dorzolamide の体内動態（第 1 報）：ラットにお ける単回投与後の吸収, 分布, 代謝抒よび排泄. 薬物動態, 10 (1): 1-17 (1995).

8) Hasegawa, T., Hara, K. and Hata, S.: Binding of dorzolamide and its metabolite, $N$-deethylated dorzolamide, to human erythrocytes in vitro. Drug Metab. Dispos., 22: 377-382 (1994).

9) Lin, J. H., Chen I. W. and Lin T. H.: Species-dependent stereopharmacokinetics of MK-927, a potent carbonic anhydrase inhibitor. Drug Metab. Dispos., 19: 816-822 (1991).

10) Maren, T. H.: Carbonic anhydrase: chemistry, physiology and inhibition. Physiol. Rev., 47: 595781 (1967).

11) Sanyal, G., Swenson, E. R., Pessah, N. I. and Maren, T. H.: The carbon dioxide hydration activity of skeletal muscle carbonic anhydrase: Inhibition by sulfonamides and anions. Mol. Pharmacol., 22: 211-220 (1982).

12) Osborne, W. R. A. and Tashian, R. E.: Dissociation constants for carbonic anhydrase-sulfonamide binding by high-performance liquid chromatography. Anal. Biochem., 137: 302-306 (1984).

13) Lin, J. H., Chen I. W. and deLuna, F. A.: Dose-dependent pharmacokinetics of MK-417, a potent carbonic anhydrase inhibitor, in experimental polycythemic and anemic rats. Pharm. Res., 8: 608-614 (1991).

14) Lin, J. H., Ulm, E. H. and Los, L. E.: Dose-dependent stereopharmacokinetics of 5,6-dihydro-4H4 (isobutylamino) thieno (2,3-B) thiopyran-2-sulfonamide-7,7-dioxide, a potent carbonic anhydrase inhibitor, in rats. Drug Metab. Dispos., 19: 233-238 (1991).

15) McIntosh, J. E. A.: Carbonic anhydrase isoenzymes in the erythrocytes and dorsolateral prostate of the rat. Biochem. J., 114: 463-476 (1969).

16) Wistrand, P. J. and Wåhlstrand, T.: Rat renal and erythrocyte carbonic anhydrases purification and properties. Biochim. Biophys. Acta., 481: 712-721 (1977). 
17) Deutsch, H. F.: Review, Carbonic anhydrases. Int. J. Biochem., 19: 101-113 (1987).

18) Lönnerholm, G., Wistrand, P. J. and Bárány, E.:
Carbonic anhydrase isoenzymes in the rat kidney. Effects of chronic acetazolamide treatment. Acta Physiol. Scand., 126: 51-60 (1986). 